\title{
Learning styles among first professional northern and central India medical students during digitization
}

This article was published in the following Dove Press journal:

Advances in Medical Education and Practice

\section{Rachna Parashar' \\ Sandip Hulke' \\ Abhijit Pakhare ${ }^{2}$ \\ 'Department of Physiology, AlIMS Bhopal, Madhya Pradesh 462024, India; ${ }^{2}$ Department of Community and Family Medicine, AllMS Bhopal, Madhya Pradesh 462024, India}

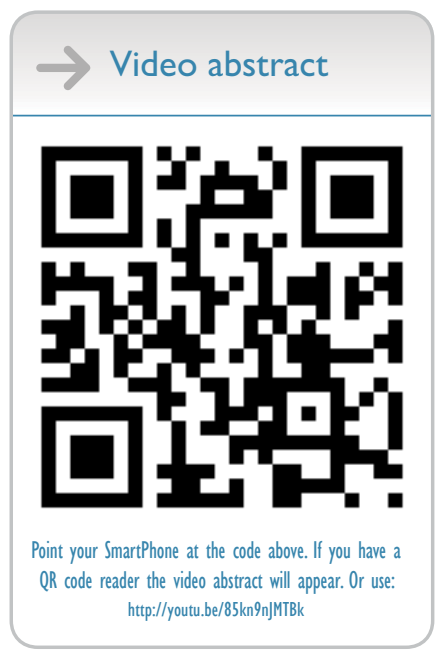

Correspondence: Rachna Parashar Department of Physiology, AlIMS Bhopal, TYPE 5, All India institute residential complex, saket nagar Bhopal, Madhya Pradesh 462024, India

Tel +9l 9425 II 498।

Email drrachnaparashar@rediffmail.com
Background: Learning style is an individual's natural or habitual pattern of acquiring and processing information in learning situations. Different sensory modalities are used by different types of medical students for assimilating the knowledge and information. Currently, the usage of electronic tools for teaching is widespread that can influence learning styles.

Methods: The purpose of this study was to know the pattern of learners among first- and second-year medical students from different institutions in India. For this purpose, we have used latest English Version 7.0 of the Visual-Aural-Read/write-Kinesthetic.

Results: Analysis was carried out using the IBM SPSS Version 21 software. Numerical variables were summarized by mean and SD or median and IQR as appropriate. Differences in scores among Visual-Aural-Read/write-Kinesthetic-learning styles were tested by Friedman's test with post hoc pair wise comparison. Pattern of learning styles was different, and it was statistically significant $(P<0.001)$. In this study, aural (median score 6) and kinesthetic (median score 6) styles were preferred. Pair-wise comparisons revealed that each style was different from each other except kinesthetic and aural.

Conclusion: Results of the study suggest that to improve learning, one should try to use multimodal styles with special emphasis given to auditory and kinesthetic modes especially among first professionals in medical education during digitization.

Keywords: learning styles, medical education, VARK, digitization

\section{Introduction}

Learning is an acquired appropriate response to a stimulus, which tends to change the environment of the organisms. It has been known since long that there are various factors, which can influence learning in medical education, including teacher factors, eg, mismatched styles, avoiding, "making things worse", unsure of self, and inadequate observations; system factors, eg, work overload (both sides), inadequate supervision, poor records, and poor support systems; and learner factors, eg, selective learning style, learning disability, and substance abuse. Understanding the learner factors is crucial to facilitate learning as well as to improve other two teacher- and system-related factors. Learning style is an individual's natural or habitual pattern of acquiring and processing information in learning situations. Learning styles vary from student to student and from time to time. ${ }^{1-3}$ Since we know that the brain is capable of change regeneration and growth with time, student's approaches to learning can be influenced by the perception that they gain from their learning environment.

Borges et $\mathrm{al}^{4}$ found that students' learning approach is different in electronic world. Change in the style of teaching in electronic world has brought some new ideas on 
teaching and learning. ${ }^{5}$ As we are using electronic media (power-point presentations) instead of chalk and board in first professional lectures in medical college, it has also been argued that medical teachers should not only possess content knowledge but also be acquainted with their learner's attributes in order to facilitate their learning. ${ }^{6-9}$ Considering this ideal situation makes the facilitator role much more difficult in today's medical world where facilitators are delivering their presentation on power point during lectures and students also prefers learning via YouTube or online presentations and are interested in learning via a soft copy of textbooks.

Many factors can affect student learning styles including academic achievement, brain processing, culture, and creative thinking. Fleming has described learning styles based on sensory modalities that can accommodate most of the factors. ${ }^{10}$ Sensory modalities described by Fleming are visual (V), aural (A), reading/writing (R), and kinesthetic (K) called as VARK. Different sensory modalities are used by different first professional learners for assimilating the knowledge and information. Currently, the usage of electronic tools such as power point presentations for teaching is widespread especially among first- and second-year medical students that can influence different sensory modalities and hence learning. Knowing the learning styles among learners will be useful to facilitate learning among medical students where they are expected to gain vast knowledge during their course.

Little is known about the distribution of learning preferences of first professional medical students in Indian medical education during digitization, where the culture and medical education differ greatly from western countries. However, inconsistent results of few studies from western countries exist. Therefore, we aimed to know the pattern of learners among first professional medical students, ie, first- and second-year medical students. For this purpose, we have used latest English Version 7.0 of the VARK questionnaire ${ }^{10}$ to assess learning styles among medical students from different institutions in India. The VARK instrument is specifically developed to evaluate learning styles in view of different modalities. ${ }^{11,12}$

\section{Methods}

\section{Setting and participants}

A cross-sectional study was conducted among first- and second-year medical students between 2013 and 2014 at some purposively selected medical institutes of Delhi, Uttar Pradesh, and Madhya Pradesh states. Medical students from these institutes were invited to participate in this study.

\section{Sampling and sample size}

Investigators of this study are from three different institutes located in states of Madhya Pradesh, Uttar Pradesh, and Delhi in India. Approximately 300 first-year and 300 second-year medical students from these institutes were eligible to participate in this study.

\section{Instrument or methodology}

The VARK questionnaire has been specifically developed in the context of assessing different styles based on sensory modalities of learning. VARK has been used in some countries to assess learning style preferences of students previously. English Version 7 of the VARK questionnaire was used in this study. The questionnaire measures four sensory preferences of perception. VARK consists of 16 questions with four options each. The purpose of each question is to know the pattern of learning style of medical students. Learners can choose more than one option for identifying the preferences for multiple learning styles. Satisfactory levels of reliability and validity of the VARK have been reported using different methods and techniques. ${ }^{13}$

\section{Procedure}

The study was approved by the Institutional Human Ethics Committee of AIIMS Bhopal. The VARK questionnaire was distributed to first-year medical students just a few months after their admission and to second-year students just after passing the first year. The purpose of the study was explained to them in details. Participation was voluntary for students, and written informed consent was obtained from willing students. Students were not required to write their names on the questionnaire and relieved from any kind of pressure. They were allowed to choose multiple options as per their preferences.

\section{Statistical analysis}

Analysis was done using the IBM SPSS Version 21 software (IBM Corporation, Armonk, NY, USA). Numerical variables were summarized by using mean and SD or median and IQR as appropriate. Differences in scores among VARK-learning styles were tested by Friedman's test with post hoc pairwise comparison.

\section{Results}

A total of 600 students were invited, of whom 545 students gave consent for participation leading to a response rate of approximately $91 \%$. Among respondents, 330 respondents 
were males with the mean age of 19.6 years (SD 1.6 years) and 215 respondents were females with the mean age of 19.2 years (SD 2.3 years). Table 1 and Figure 1 show descriptive statistics of scores of VARK questionnaire for different learning styles.

We compared learning styles among students using Friedman's test. The pattern of learning styles was different, and some learning styles were preferred more than other; this difference was statistically significant $(P<0.001)$. In this study, aural (median score 6) and kinesthetic (median score 6) styles were preferred over other styles by students as shown in Table 1. Pair-wise comparisons (Table 2) reveal that each style was different from each other except kinesthetic and aural.

Students gave more multi-choice responses than a single choice. When we stratified data by the single-choice response and multi-choice response, aural and kinesthetic styles were common in multi-choice responses too. In single-choice responses, visual style was reported least (median score 3) and other styles were similar (Table 3).

We have done gender-wise comparisons, and pattern of learning styles was similar in both male and female students, meaning that no significant difference was found (Table 4).

\section{Discussion}

Different studies have been done on the type of learners based on different hypotheses, but a very few studies or no have been done among first-year Indian medical professionals during digitization. In the present study, we have used VARK questionnaire in medical students for evaluating learning style preferences. Participants were first- and second-year undergraduate medical students from different colleges of northern (Delhi and Uttar Pradesh) and central (Bhopal) India. Students from different regions and cultural background of India were enrolled in these institutes. Our study shows that medical students have multimodal learning styles and kinesthetic and aural styles are preferred over others.

Learning styles based on four sensory modalities of VARK were described by Fleming. ${ }^{12}$ A visual student prefers visual mode, ie, by seeing, and an aural student prefers listening techniques. Read/write learners prefer reading and writing for assimilating and accommodating the information. A kinesthetic student experiences by doing. According to Valerdi et al, multimodal type of learners may be in a situation that they can shift from mode to mode depending on the context or are satisfied only when they have had their input in all their preferred modes. ${ }^{14-16}$

The present study also suggested that among four learning styles relatively more preference was for aural and kinesthetic styles. A similar pattern of learner responses was seen during

Table 2 Friedman's test, post hoc pairwise comparison among learning styles

\begin{tabular}{|l|l|l|l|}
\hline Comparison pair & $\begin{array}{l}\text { Test } \\
\text { statistic }\end{array}$ & $\begin{array}{l}\text { Standard } \\
\text { error }\end{array}$ & P-value \\
\hline Visual vs read/write & -0.628 & 0.078 & $<0.00 \mathrm{I}$ \\
\hline Visual vs kinesthetic & -0.938 & 0.078 & $<0.00 \mathrm{I}$ \\
\hline Visual vs aural & $-1.02 \mathrm{I}$ & 0.078 & $<0.00 \mathrm{I}$ \\
\hline Read/write vs kinesthetic & -0.309 & 0.078 & $<0.00 \mathrm{I}$ \\
\hline Read/write vs aural & 0.393 & 0.078 & $<0.00 \mathrm{I}$ \\
\hline Kinesthetic vs aural & 0.083 & 0.078 & $\mathrm{I} .000$ \\
\hline
\end{tabular}

Table I Descriptive statistics for VARK score $(n=545)$

\begin{tabular}{|l|l|l|l|l|l|}
\hline Learning styles & Mean & SD & Median & Percentile 25 & Percentile 75 \\
\hline Visual & 3.9 & 2.3 & 4.0 & 2.0 & 5.0 \\
\hline Aural & 6.0 & 2.5 & 6.0 & 4.0 & 7.0 \\
\hline Read/write & 5.1 & 2.2 & 5.0 & 4.0 & 6.0 \\
\hline Kinesthetic & 5.8 & 2.6 & 6.0 & 4.0 & 7.0 \\
\hline
\end{tabular}

Abbreviation: VARK, Visual-Aural-Read/write-Kinesthetic.

Related-sample Friedman's two-way analysis of variance by ranks

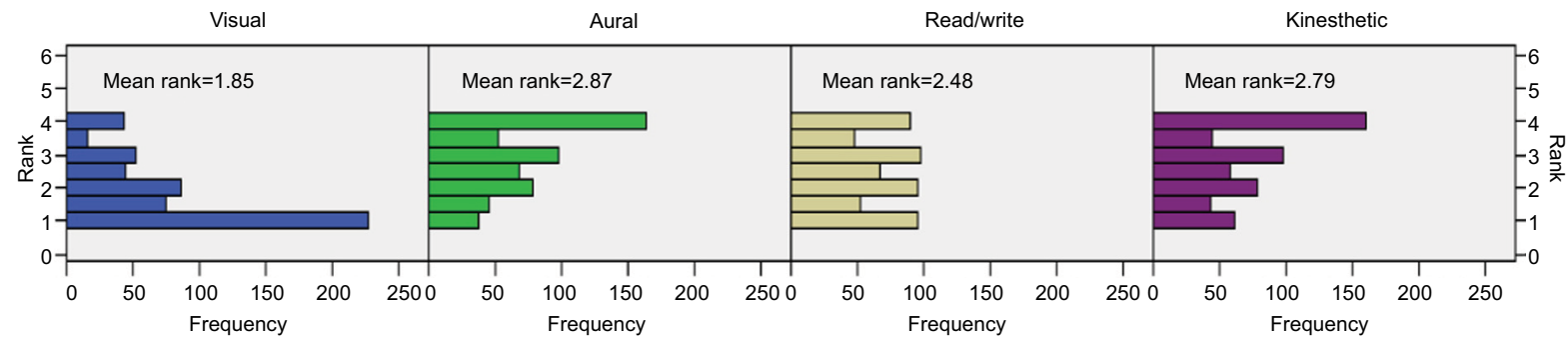

Figure I Distribution of scores by learning styles. 
Table 3 Distribution of VARK scores by response type

\begin{tabular}{|c|c|c|c|c|c|c|}
\hline \multicolumn{2}{|c|}{ Learning styles } & \multirow{2}{*}{$\begin{array}{l}\text { Mean } \\
4.5\end{array}$} & \multirow{2}{*}{$\begin{array}{l}\text { SD } \\
2.4\end{array}$} & \multirow{2}{*}{$\begin{array}{l}\text { Median } \\
4.0\end{array}$} & \multirow{2}{*}{$\begin{array}{l}\text { Percentile } 25 \\
3.0\end{array}$} & \multirow{2}{*}{$\begin{array}{l}\text { Percentile } 75 \\
6.0\end{array}$} \\
\hline Multiple & Visual & & & & & \\
\hline responses for & Aural & 6.6 & 2.5 & 6.0 & 5.0 & 8.0 \\
\hline items & Read/write & 5.6 & 2.2 & 5.0 & 4.0 & 7.0 \\
\hline & Kinesthetic & 6.6 & 2.5 & 7.0 & 5.0 & 8.0 \\
\hline \multirow{4}{*}{$\begin{array}{l}\text { Single } \\
\text { response for } \\
\text { items }\end{array}$} & Visual & 2.9 & 1.7 & 3.0 & 2.0 & 4.0 \\
\hline & Aural & 4.7 & 1.9 & 5.0 & 3.0 & 6.0 \\
\hline & Read/write & 4.1 & 1.8 & 4.0 & 3.0 & 5.0 \\
\hline & Kinesthetic & 4.3 & 1.9 & 4.0 & 3.0 & 6.0 \\
\hline
\end{tabular}

Abbreviation: VARK, Visual-Aural-Read/write-Kinesthetic.

Table 4 Gender wise comparison of learning styles

\begin{tabular}{|c|c|c|c|c|c|}
\hline \multirow{3}{*}{$\begin{array}{l}\text { Learning } \\
\text { styles }\end{array}$} & \multicolumn{4}{|c|}{ Gender } & \multirow{3}{*}{$\begin{array}{l}P \text {-value } \\
\text { (between } \\
\text { group) }\end{array}$} \\
\hline & \multicolumn{2}{|l|}{ Male } & \multicolumn{2}{|c|}{ Female } & \\
\hline & Mean & SD & Mean & SD & \\
\hline Visual & 4.06 & 2.26 & 3.76 & 2.39 & \multirow[t]{4}{*}{0.633} \\
\hline Aural & 5.93 & 2.45 & 5.98 & 2.59 & \\
\hline Read/write & 5.18 & 2.31 & 5.04 & 2.12 & \\
\hline Kinesthetic & 5.85 & 2.52 & 5.79 & 2.65 & \\
\hline
\end{tabular}

digitization among single-choice responders and multi-choice responders, meaning that kinesthetic and aural styles are preferred more whether learners are falling in the category of multimodal or unimodal. A similar pattern of multimodal preferences was suggested by the studies of Lujan, ${ }^{15}$ Choudhary, ${ }^{16}$ and Samarakoon et a $1{ }^{17}$ with slightly different sensory mode as Lujan et al found kinesthetic inclination more while Choudhary et al suggested aural preference among learners, but multimodal responses were in contrast to studies of Panambur et a $1^{18}$ where unimodal learners were homogenously distributed across the four VARK categories.

Results from above studies suggest that educators should cater for all the learning styles, which are the challenge because, in millennium electronic world, both learners and facilitators use electronic mode for learning that may change the preferred learning styles in the present world. Lecture classes of basic sciences, especially anatomy, physiology, and biochemistry, consist of power point presentations, and some uses chalk board in medical education of millennium students. These modalities can just stimulate visual learners, which are among least in our and several other study results. Understanding it also depends on the quality of power point presentations and teachers writing skills on board.

Thus, despite aural and kinesthetic modes are the more preferred ones, less attention to it is given in classic classroom teaching for the first professional in medical education. This can be improved upon by concentrating on following points: ${ }^{19-21}$
1. Improving the facilitator's speech quality that includes intensity and pitch.

2. Try to incorporate problem solving and showing relevant cases and incorporate the practical relevant to topics that can enhance their learning by enhancing their kinesthetic mode.

3. Relevant to topic practical/demonstrations incorporated should go side by side to their lecture classes.

4. Related topics in basic sciences should run together for better understanding.

5. Smart board teaching.

According to Samarakoon, learning style varies even among undergraduates and postgraduates and also found to vary among first-year and final-year medical students. We have restricted our study to first- and second-year millennial medical students to improve the basic science (anatomy physiology and biochemistry) teachings. Results shown in our study were not different among female subjects. Hence at the end, it is concluded that, to improve learning, one should try to use multimodal styles with special emphasis given to auditory and kinesthetic modes especially among basic science teaching in millennium medical education.

\section{Limitation of study}

This was a cross-sectional study conducted among first- and second-year medical students of three institutes from northern and central parts of India, and thus, results of the study may not be generalized to all Indian medical students. We have focused on only first-year students and second-year students who had just completed first-year; thus, result should not be generalized to all students as learning style preferences may change with their progression in course.

\section{Conclusion}

Results of our study may suggest that to improve learning one should try to use multimodal styles with special emphasis 
given to auditory and kinesthetic modes especially among first professionals in medical education during digitization.

\section{Acknowledgment}

We are especially thankful for our medical students and my colleagues in different medical institutes to give their full support time to fulfill our study.

\section{Disclosure}

The authors report no conflicts of interest in this work.

\section{References}

1. Zoghi M, Brown T, Williams B, et al. Learning style preferences of Australian health science students. JAllied Health. 2010;39(2):95-103.

2. Honigsfeld A. A comparative analysis of the learning styles of adolescents from diverse nations by age, gender, academic achievement level and nationality. Humanities and Social Sciences. 2001;62:969.

3. Slater JA, Lujan HL, Dicarlo SE. Does gender influence learning style preferences of first-year medical students? Adv Physiol Educ. 2007;31(4):336-342.

4. Borges NJ, Manuel RS, Elam CL, Jones BJ. Comparing millennial and generation X medical students at one medical school. Acad Med. 2006;81(6):571-576.

5. Townsend T, Bates R. Handbook of Teacher Education. Globalization, Standards and Professionalism in Times of Change. Dordrecht, The Netherlands: Springer; 2007.

6. Wang W. Factors Affecting Learners' Attention to Teacher Talk in Nine ESL Classrooms. Electronic Journal for English as a Second Language. 2015; 19(1):1-20.

7. Steinert Y, Levitt C. Working with the "problem" resident: guidelines for definition and intervention. Fam Med. 1993;25(10):627-632.

8. Gudmundsdottir S, Shulman L. Pedagogical content knowledge in social studies. Scand J Educ Res. 1987;31(2):59-70.
9. James W, Gardner D. Learning styles: implications for distance learning. New Directions for Adult and Continuing Education. 1995;67:19-31.

10. Fleming N. Teaching and Learning Styles. VARK Strategies. Christ Church, New Zealand: Microfilm Digital Print and Copy Center; 2001.

11. Fuster JM, Joaquin M. Frontal lobe and cognitive development. J Neurocytol. 2002;31(3-5):373-385.

12. Fleming $\mathrm{N}$. [webpage on the Internet]. VARK: a guide to learning styles 2007. Available from: http://www.vark learn.com/english/index.asp. Accessed July 24, 2011.

13. Leite WL, Svinicki M, Shi Y. Attempted validation of the scores of the VARK: learning styles inventory with multitrait-multimethod confirmatory factor analysis models. Educ Psychol Meas. 2010;70(2): 323-339.

14. Valerdi R, Ferris T, Jain R, Joseph K. An exploration of matching teaching to the learning preferences of systems engineering graduate students. INCOSE. 2009;19(1):1-2284

15. Lujan HL, Dicarlo SE. First-year medical students prefer multiple learning styles. Adv Physiol Educ. 2006;30(1):13-16.

16. Choudhary R, Dullo P. Gender differences in learning style preferences of first year medical students. Pak J Physiol. 2011;7:42-45.

17. Samarakoon L, Fernando T, Rodrigo C, Rajapakse S. Learning styles and approaches to learning among medical undergraduates and postgraduates. BMC Med Educ. 2013;13(1):42.

18. Panambur S, Nambiar V, Heming T. Learning style preferences of preclinical medical students in oman. Oman Med J. 2014;29(6): 461-463.

19. Seth V, Upadhyaya P, Ahmad M, Moghe V. PowerPoint or chalk and talk: perceptions of medical students versus dental students in a medical college in India. Adv Med Educ Pract. 2010;2010(1): $11-16$.

20. Kar M, Roy H, Ghosh A, et al. Lecture classes in human anatomy: the students' perceptions. J Clin Diagn Res. 2013;7(6): 1093-1098.

21. Coles C. How students learn: the process of learning. In: Jolly B, Rees L. editors. Medical Education in the Millennium. Oxford: Oxford University Press; 1998;63-82.
Advances in Medical Education and Practice

\section{Publish your work in this journal}

Advances in Medical Education and Practice is an international, peerreviewed, open access journal that aims to present and publish research on Medical Education covering medical, dental, nursing and allied health care professional education. The journal covers undergraduate education, postgraduate training and continuing medical education

\section{Dovepress}

including emerging trends and innovative models linking education, research, and health care services. The manuscript management system is completely online and includes a very quick and fair peer-review system. Visit http://www.dovepress.com/testimonials.php to read real quotes from published authors. 